\title{
Raphael Dalleo
}

American Imperialism's Undead: The Occupation of Haiti and the Rise of Caribbean Anticolonialism, 1915-1950. Charlottesville: University of Virginia Press, 2016. xii + 247 pp. (Paper US\$35.00)

The U.S. Occupation of Haiti that began in 1915 is, in Raphael Dalleo's telling, the undead of American imperialism. Putatively put to rest with the withdrawal of the Marines in 1934, it walks Caribbean islands still, in bodies of discourse animated by that encounter. Its persistence may be observed in the unexpected routes traveled by exoticism's tropes and in the shapes of Caribbean radicalism and African diasporic anticolonialism between 1915 and 195 .

From critiques cast in the mold of James Weldon Johnson's Nation articles to the vogue for tales involving snakes and zombies, Dalleo traces the impact of the occupation's discursive preoccupations in the defining works of Caribbean radicals and writers C.L.R. James, Cyril Briggs, Richard Moore, Grace Campbell, Amy Jacques Garvey, Eulalie Spence, Claude McKay, Eric Walrond, George Padmore, Alejo Carpentier, George Lamming, Jean Rhys, and others. This impact is the more notable because of the ways it has been hidden from view. For two decades, coincident with the emergence of Caribbean and African diasporic anticolonialism, Caribbean writers and activists living in Harlem, Paris, London, and Germany, as well as at home on the islands, engaged radical critiques of the occupation. Why, then, has the historical and literary record all too often remained deaf to the resonance of those critiques - and to the significance of the occupation as crucial to the emergence of anticolonialism in the region?

Drawing on Sybille Fischer's approach to the Haitian Revolution in Modernity Disavowed (2004), Dalleo answers with a deft excavation of the patterns of disavowal that have elided the occupation. Ironically, he finds, the very developments that ultimately raised up the memory fortunes of the Revolution produced the occupation's erasure. The uses of that earlier triumph afforded it a place of honor in narratives of Caribbean and African national emergence, while the occupation's interruption of black sovereignty and the impact of sensationalist white writers on Caribbean literature disrupt and trouble national mythologies.

The book's first two chapters reveal key mechanisms of this disavowal. Chapter 1, "'The Independence So Hardly Won Has Been Maintained," finds telling ellipses alongside evidence of the occupation's unnamed presence in James's turn toward Haitian history. We see James in 1931 "writing around the specter of the occupation," his prose peppered with signs linked to the Marines' presence in Haiti (p. 3o) and exhibiting anxiety in assertions of Haitians' uninterrupted sovereignty. Chapter 2, on West Indian radicals and international

(C) MARY A. RENDA, 2018 | DOI: 10.1163/22134360-09201020

This is an open access article distributed under the terms of the prevailing CC-BY-NC license at the time of publication. 
Communism in Harlem, demonstrates that Weldon Johnson's critique of the National City Bank in Haiti shifted the terms of Briggs's analysis of neocolonialism, and opened a space for greater receptivity among Caribbean radicals to Lenin's focus on financial imperialism, with wide-ranging effects in subsequent nonnationalist anticolonial imaginings across the region, from Cuba to Martinique and Trinidad.

Chapter 3 takes up the richly textured significance of McKay's Haitian voicings in Home to Harlem and Banjo and Walrond's use of exotic themes to mount challenges to U.S. imperial conceits and projects. Dalleo traces the complex networks of mentoring, publication, readership, and influence that connected McKay and Walrond to key sites and figures of black internationalism, including Leopold Sedar Senghor and Aimé Césaire. The influence of these networks, by turns generative and troubling, is further explored in an illustrative chapter on the Hispanophone Caribbean - "Afroantillanismo, the Marvelous Real, and the Occupation: Carpentier from Cuba to Paris to Haiti" - and in a discussion of Rhys and Lamming in the book's conclusion.

An important accomplishment of American Imperialism's Undead is its recuperation of the significance of actors whose radicalism was shaped by their engagement with the occupation and whose importance to pan-African and Caribbean anticolonial radicalism has been underplayed. Chapter 4, "Gendering the Occupation," focuses on the women of the Universal Negro Improvement Association, whose "community feminism" opened spaces for Haitian voices, challenged masculinist emphases, and made critical contributions to the work of male Caribbean anticolonialists (pp.110-12) and black female playwrights like Spence, who laced visions of gender solidarity with critiques of imperialism and capital. Chapter 6 reveals Padmore's important role in shaping African and Caribbean programs for decolonization, frequently employing the case of Haiti to illustrate the dangers of neocolonialism. His ties to Jomo Kenyatta and others illustrate how opposition to the occupation in and beyond Haiti helped to shape emergent anticolonial nationalism in Africa.

With skillful research and probing analyses, Dalleo shows the difference a focus on the occupation makes as he reveals the lively cross-fertilizations that shaped Caribbean and African diasporic thought in the middle decades of the twentieth century. American Imperialism's Undead establishes the defining role played by the occupation in Caribbean self-fashioning and in the emergence and evolution of anticolonialism between 1915 and 1950.

Mary A. Renda

Department of History, Mount Holyoke College

mrenda@mtholyoke.edu 